\title{
BMR
}

\section{Analysis of genetic diversity of Laeliinae (Orchidaceae) in the State of Sergipe using ISSR markers}

\author{
M.F. Arrigoni-Blank ${ }^{1}$, M.S. Santos ${ }^{1}$, A.F. Blank ${ }^{1}$, A.R.C. Rabbani ${ }^{1}$, \\ R. Silva-Mann ${ }^{1}$, J.B. Santos ${ }^{2}$, A.S. Costa ${ }^{1}$ and T.S.A. Menezes ${ }^{1}$ \\ ${ }^{1}$ Laboratório de Cultura de Tecidos e Melhoramento Vegetal, \\ Departamento de Engenharia Agronômica, \\ Universidade Federal de Sergipe, São Cristóvão, SE, Brasil \\ ${ }^{2}$ Laboratório de Biologia Molecular, Departamento de Biologia, \\ Universidade Federal de Lavras, Lavras, MG, Brasil \\ Corresponding author: M.F. Arrigoni-Blank \\ E-mail: arrigoni@ufs.br
}

Genet. Mol. Res. 15 (2): gmr.15027997

Received November 5, 2015

Accepted December 14, 2015

Published June 3, 2016

DOI http://dx.doi.org/10.4238/gmr.15027997

\begin{abstract}
The Orchidaceae represent one of the largest and most diverse families on the planet. However, this family is constantly threatened by predators and by the advancement of urban centers over its natural habitats. The objective of this study was to use inter-simple sequence repeat markers to evaluate the genetic diversity between orchid accessions of the Laeliinae subtribe, which comprise part of the Orchidaceae study collection at the Department of Agronomic Engineering of the Federal University of Sergipe. DNA was extracted from each specimen by using an adapted $2 \%$ cetyltrimethyl ammonium bromide protocol. Similarity between individuals was calculated using the Jaccard method. Clustering was carried out by the unweighted pair group method with arithmetic mean method, with resampling and 10,000 bootstraps. Eighty-seven fragments were obtained, all of which were polymorphic, revealing high variability between accessions. The mean similarity was $35.77 \%$ between Encyclia sp individuals,
\end{abstract}


and $35.90 \%$ between specimens of Cattleya tigrina. For Epidendrum secundum, a relationship between geographic and genetic distances was observed, and the accession collected in the southern part of the State of Sergipe (Serra de Itabaiana National Park) was more divergent than that of the other parts of the state. The data generated in this study will guide further research aimed at the ex situ conservation of these materials.

Key words: Cattleya tigrina; Conservation; Genetic diversity; Encyclia sp; Epidendrum sp; ISSR

\section{INTRODUCTION}

The orchid family contains about 35,000 species that are distributed in over 1800 genera (Watanabe, 2002) and are dispersed throughout the world, from the polar regions to equatorial deserts (Moreira et al., 2007), with greater diversity in the tropical region. This family represents $7 \%$ of all species on the planet (Altafin et al., 2003; Rech et al., 2011), and is considered by many botanists to be the most evolved of the Liliopsida (Raven et al., 2007). However, Orchidaceae is also considered to be the family with the highest percentage of endangered genera and species.

Destruction of native vegetation and the resulting loss of genetic diversity account for the vulnerability of these species. The loss of genetic variability may reduce the ability of a species to adapt to biotic and abiotic changes, intensifying the extinction process. Studies on patterns of genetic diversity within populations and the structure between populations may help to infer evolutionary mechanisms, such as genetic drift, selection, and mutation. Furthermore, the spatial genetic structure may serve as an indicator of the extent of gene flow and population divergence (George et al., 2009).

Molecular markers are used widely in studies on genetic diversity. Inter-simple sequence repeat (ISSR) markers have been used extensively in studies of diversity and genetic structure of many species, because compared to other markers, ISSR markers are more reproducible, stabler, simpler, and easier to work with (George et al., 2009; Fang et al., 2012).

Some studies involving the Orchidaceae family have evaluated the genetic diversity and conservation of native populations, such as the use of ISSR markers in the investigation of diversity in Piperia yadonii allozymes and Goodyera rosulacea, both of which revealed low variation between individuals and highlighted the immediate need for development of conservation strategies (George et al., 2009; Chung and Chung, 2010). In addition, random amplified polymorphic DNA (RAPD) and ISSR markers have been used in studies on Cymbidium sp (Sharma et al., 2011), and microsatellite markers have been used to study Dendrobium loddigesii (Cai et al., 2012).

Studies using ISSR and RAPD markers to investigate diversity in populations of Cattleya labiata from northeastern Brazil found 272 fragments, Jaccard similarity coefficients ranging from 0.14 to 0.82 , and mean similarity of $50 \%$ within populations. Although this variation is relatively high, the authors note that these populations are isolated owing to the fragmentation of the main habitat of the species (Atlantic Forest). Under these circumstances, there is a risk of losing some populations, and consequently, some alleles and characteristics that are not shared by individuals from other clusters. This limits the ability of preserving this species (Pinheiro et al., 2012).

The objective of this article was to study the genetic diversity conserved within the 
Laeliinae subtribe in the State of Sergipe. The subtribe is represented by the genera Encyclia Hook, Epidendrum L., and Cattleya Lindl.

\section{MATERIAL AND METHODS}

\section{Plant material}

Based on inventories and surveys of the flora of Sergipe, a biogeographic study was carried out on orchid populations in the state. Next, germplasm collection expeditions were carried out in the regions where these populations occur, and random sampling was carried out in these locations, as well as mapping, with the aid of a Global Positioning System (GPS) (GARMIN, Schaffhausen, Switzerland).

Exploited areas were remnants of the Atlantic Forest in the State of Sergipe, and represent the main biome in which the Orchidaceae family occurs within the state. In total, 143 individuals were collected in eight different regions.

Individuals were coded, planted in ceramic pots containing carbonized wood chips and pine bark (1:1), and kept in a greenhouse with regular watering. Species of collected accessions were identified using the taxonomic key in the ASE Herbarium of the Federal University of Sergipe (UFS).

Of the collected individuals, 31 were identified to the genus level (15 different botanical genera), and 45 to the species level. Of these, 30 individuals of the Laeliinae subtribe (13 Encyclia, 12 Epidendrum, and 5 Cattleya) (Table 1) were used to study diversity.

\begin{tabular}{|c|c|c|c|c|}
\hline Name & Code & Municipality of origin & Scientific name & Geographic data \\
\hline RD_Cat.tigrina & ORQ 162 & Riachão do Dantas & Cattleya tigrina & $11^{\circ} 04^{\prime} 30.9^{\prime \prime S} 37^{\circ} 49^{\prime} 46.2^{\prime \prime} \mathrm{W}$ \\
\hline RD_Cat.tigrinal & ORQ 166 & Riachão do Dantas & Cattleya tigrina & $11^{\circ} 04^{\prime} 33.4^{\prime \prime S} 37^{\circ} 49^{\prime} 47.9^{\prime \prime} \mathrm{W}$ \\
\hline RD_Cat.tigrina2 & ORQ 174 & Riachão do Dantas & Cattleya tigrina & $11^{\circ} 04^{\prime} 36.4^{\prime \prime S} 37^{\circ} 49^{\prime} 44.2^{\prime \prime} \mathrm{W}$ \\
\hline RD Cat.tigrina3 & ORQ 175 & Riachão do Dantas & Cattleya tigrina & $11^{\circ} 04^{\prime} 36.5^{\prime \prime S} 37^{\circ} 49^{\prime} 43.3^{\prime \prime} \mathrm{W}$ \\
\hline RD_Cat.tigrina4 & ORQ 179 & Riachão do Dantas & Cattleya tigrina & $11^{\circ} 04^{\prime} 36.7^{\prime \prime S} 37^{\circ} 49^{\prime \prime} 45.0^{\prime \prime} \mathrm{W}$ \\
\hline RI_Encyclia & ORQ 120 & Ribeira & Encyclia dichroma & $10^{\circ} 49^{\prime} 33.0^{\prime \prime S} 37^{\circ} 26^{\prime \prime} 24.0^{\prime \prime} \mathrm{W}$ \\
\hline SI_Encyclia & ORQ 017 & Serra de Itabaiana & Encyclia dichroma & $10^{\circ} 45^{\prime} 26.6^{\prime \prime S} 37^{\circ} 20^{\prime} 29.9^{\prime \prime} \mathrm{W}$ \\
\hline SI_Encyclia2 & ORQ 022 & Serra de Itabaiana & Encyclia dichroma & $10^{\circ} 45^{\prime} 31.8^{\prime \prime} \mathrm{S} 37^{\circ} 20^{\prime} 29.4^{\prime \prime} \mathrm{W}$ \\
\hline RI Encyclia2 & ORQ 088 & Ribeira & Encyclia $\mathrm{sp}$ & $10^{\circ} 49^{\prime} 33.0^{\prime \prime S} 37^{\circ} 26^{\prime} 24.0^{\prime \prime} \mathrm{W}$ \\
\hline RdasP Encyclia & ORQ 126 & Rio das Pedras & Encyclia $\mathrm{sp}$ & $10^{\circ} 47^{\prime} 18.0^{\prime \prime S} 37^{\circ} 25^{\prime} 47.1 " \mathrm{~W}$ \\
\hline RdasP_Encyclia2 & ORQ 127 & Rio das Pedras & Encyclia $\mathrm{sp}$ & $10^{\circ} 47^{\prime} 18.0^{\prime \prime} \mathrm{S} 37^{\circ} 25^{\prime} 47.1^{\prime \prime} \mathrm{W}$ \\
\hline RdasP_Encyclia3 & ORQ 128 & Rio das Pedras & Encyclia $\mathrm{sp}$ & $10^{\circ} 47^{\prime} 18.0^{\prime \prime} \mathrm{S} 37^{\circ} 25^{\prime} 47.1^{\prime \prime} \mathrm{W}$ \\
\hline RdasP_Encyclia4 & ORQ 132 & Rio das Pedras & Encyclia $\mathrm{sp}$ & $10^{\circ} 47^{\prime} 18.0^{\prime \prime} \mathrm{S} 37^{\circ} 25^{\prime} 47.6^{\prime \prime} \mathrm{W}$ \\
\hline SI Encyclia3 & ORQ 035 & Serra de Itabaiana & Encyclia $\mathrm{sp}$ & $10^{\circ} 45^{\prime} 07.0^{\prime \prime} \mathrm{S} 37^{\circ} 21^{\prime} 57.0^{\prime \prime} \mathrm{W}$ \\
\hline SI Encyclia4 & ORQ 037 & Serra de Itabaiana & Encyclia $\mathrm{sp}$ & $10^{\circ} 45^{\prime} 10.6^{\prime \prime S} 37^{\circ} 21^{\prime} 59.6^{\prime \prime} \mathrm{W}$ \\
\hline SI Encyclia5 & ORQ 039 & Serra de Itabaiana & Encyclia $\mathrm{sp}$ & $10^{\circ} 45^{\prime} 10.6^{\prime \prime S} 37^{\circ} 21^{\prime} 59.6^{\prime \prime} \mathrm{W}$ \\
\hline SI_Encyclia6 & ORQ 043 & Serra de Itabaiana & Encyclia $\mathrm{sp}$ & $10^{\circ} 45^{\prime} 25.9^{\prime \prime} \mathrm{S} 37^{\circ} 22^{\prime} 05.6^{\prime \prime} \mathrm{W}$ \\
\hline SI_Encyclia7 & ORQ 054 & Serra de Itabaiana & Encyclia $\mathrm{sp}$ & $10^{\circ} 45^{\prime} 09.3^{\prime \prime S} 37^{\circ} 21^{\prime} 58.0^{\prime \prime} \mathrm{W}$ \\
\hline SI_Encyclia8 & ORQ 057 & Serra de Itabaiana & Encyclia $\mathrm{sp}$ & $10^{\circ} 45^{\prime} 07.0^{\prime \prime} \mathrm{S} 37^{\circ} 21^{\prime} 57.0^{\prime \prime} \mathrm{W}$ \\
\hline SI_Encyclia9 & ORQ 058 & Serra de Itabaiana & Encyclia $\mathrm{sp}$ & $10^{\circ} 45^{\prime} 32.0^{\prime \prime} \mathrm{S} 37^{\circ} 20^{\prime} 30.7^{\prime \prime} \mathrm{W}$ \\
\hline RdasP E.secudum & ORQ 137 & Rio das Pedras & Epidendrum secundum & $10^{\circ} 47^{\prime} 18.0^{\prime \prime S} 37^{\circ} 25^{\prime} 47.6^{\prime \prime} \mathrm{W}$ \\
\hline RdasP_E.secudum2 & ORQ 141 & Rio das Pedras & Epidendrum secundum & $10^{\circ} 47^{\prime} 18.0^{\prime \prime} \mathrm{S} 37^{\circ} 25^{\prime} 47.6^{\prime \prime} \mathrm{W}$ \\
\hline TG_E.secudum & ORQ 046 & Serra de Itabaiana & Epidendrum secundum & $10^{\circ} 45^{\prime} 20.5^{\prime \prime S} 37^{\circ} 22^{\prime} 06.4^{\prime \prime} \mathrm{W}$ \\
\hline SI_E.secudum2 & ORQ 008 & Serra de Itabaiana & Epidendrum $\mathrm{sp}$ & $10^{\circ} 45^{\prime} 39.7^{\prime \prime S} 37^{\circ} 20^{\prime} 24.7^{\prime \prime} \mathrm{W}$ \\
\hline SI_E.secudum3 & ORQ 020 & Serra de Itabaiana & Epidendrum $\mathrm{sp}$ & $10^{\circ} 45^{\prime} 30.3^{\prime \prime S} 37^{\circ} 20^{\prime} 30.7^{\prime \prime} \mathrm{W}$ \\
\hline SI E.secudum4 & ORQ 024 & Serra de Itabaiana & Epidendrum $\mathrm{sp}$ & $10^{\circ} 45^{\prime} 31.8^{\prime \prime S} 37^{\circ} 20^{\prime} 29.4^{\prime \prime} \mathrm{W}$ \\
\hline SI_E.secudum5 & ORQ 055 & Serra de Itabaiana & Epidendrum $\mathrm{sp}$ & $10^{\circ} 45^{\prime} 07.1^{\prime \prime} \mathrm{S} 37^{\circ} 21^{\prime} 57.0^{\prime \prime} \mathrm{W}$ \\
\hline SI E.secudum7 & ORQ 062 & Serra de Itabaiana & Epidendrum sp & $10^{\circ} 44^{\prime} 57.3^{\prime \prime S} 37^{\circ} 21^{\prime} 04.2^{\prime \prime} \mathrm{W}$ \\
\hline X_E.059 & ORQ 059 & Serra de Itabaiana & Epidendrum sp & $10^{\circ} 45^{\prime} 07.0^{\prime \prime S} 37^{\circ} 21^{\prime} 57.0^{\prime \prime} \mathrm{W}$ \\
\hline X_E.116 & ORQ 116 & Serra de Itabaiana & Epidendrum sp & $10^{\circ} 44^{\prime} 57.3^{\prime \prime S} 37^{\circ} 21^{\prime} 04.2^{\prime \prime} \mathrm{W}$ \\
\hline
\end{tabular}




\section{SSR markers}

Young leaves were collected from the UFS collection and submitted to an adapted DNA extraction method using 2\% cetyltrimethyl ammonium bromide (CTAB) (Doyle, 1991). About $1 \mathrm{~g}$ young leaf was macerated in a mortar with $10 \mathrm{~mL} \mathrm{2 \%} \mathrm{CTAB} \mathrm{buffer.} \mathrm{Reactions}$ were carried out at the Molecular Genetics Laboratory of Department of Biology, Federal University of Lavras, UFLA (Brazil). The total reaction volume was $12 \mathrm{~mL}$, which contained $2.25 \mu \mathrm{L}$ genomic DNA (10 ng/ $\mu \mathrm{L}), 2.25 \mu \mathrm{L}$ primer, $1.0 \mathrm{~mL}$ buffer, $0.66 \mu \mathrm{L}$ dNTP $(10 \mathrm{mM})$, $0.6 \mu \mathrm{L}$ Taq DNA polymerase, and $5.25 \mathrm{~mL}$ ultrapure water. Eight primers were used (Table 2).

Table 2. Sequences and annealing temperature of inter simple sequence repeat (ISSR) primers used to characterize orchids collected in municipalities of the State of Sergipe (Brazil).

\begin{tabular}{l|l|c}
\hline Primer & Sequence $\left(5^{\prime}-3^{\prime}\right)$ & Annealing temperature $\left({ }^{\circ} \mathrm{C}\right)$ \\
\hline ISSR 3 & TG GA TG GA TG GA TG GA & 55 \\
\hline ISSR 6 & AC TG AC TG AC TG AC TG & 55 \\
\hline ISSR 7 & GTG GTG GTG GTG GTG & 55 \\
\hline ISSR 9 & AC AC AC AC AC AC AC AC-CG & 55 \\
\hline ISSR 15 & CA CA CA CA CA CA CA CA-AG & 50 \\
\hline ISSR 813 & CTC TCT CTC TCT CTC TT & 55 \\
\hline ISSR 827 & ACA CAC ACA CAC ACA CG & 48 \\
\hline ISSR 848 & CAC ACA CAC ACA CAC ARG & 50 \\
\hline
\end{tabular}

Amplification was carried out using 1.5\% agarose gel with $4 \mathrm{~mL}$ per $100 \mathrm{~mL} \mathrm{RED}^{\circledR}$ gel (Biotium, Hayward, CA, USA), run at $90 \mathrm{~V}$ for $3 \mathrm{~h}$. Amplified products were visualized and photographed under ultraviolet light in a KODAK EDAS 290 photo documentation system.

\section{Statistical and genetic analyses}

Electrophoretic profiles of ISSR markers were transformed into a binary matrix. The presence of a fragment in a particular individual was represented by 1 , and the absence of the same fragment was represented by 0 . Similarity was calculated using the Jaccard method. Accessions were clustered based on similarity, using the unweighted pair group method with arithmetic mean (UPGMA). To evaluate the robustness of clustering between genotypes, bootstrap resampling was carried out with the same size of the original sample. For each resampling level, 10,000 bootstrap samples were obtained. This analysis was carried out using the FreeTree software (Pavlicek et al., 1999). The dendrogram was obtained by the TreeView software (Page, 1996).

\section{RESULTS}

The eight ISSR primers produced a total of 87 fragments, all of which were polymorphic, with a mean $\sim 11$ fragments per primer. The highest number of bands was obtained by ISSR 7 (17 fragments), and the lowest number of bands was obtained by ISSR 6 ( 7 fragments).

Similarity between individuals of the Encyclia genus (Table 3) ranged from $4 \%$ (between individuals collected, in the town of Rio das Pedras - municipality of Itabaiana, and another, in the Serra de Itabaiana National Park) to $76 \%$ (between individuals of the National Park). The mean similarity for this genus was $35.77 \%$. 
Table 3. Jaccard similarity (\%) of individuals of the genus Encyclia Hook from the Orchidaceae collection of the Universidade Federal de Sergipe, collected in municipalities of the State of Sergipe (Brazil).

\begin{tabular}{l|c|c|c|c|c|c|c|c|c|c|c|c|c}
\hline & SI_En & SI_En2 & SD_En & RI_En & SI_En3 & SI_En4 & SI_En5 & SI_En6 & SI_En7 & RP_En & SI_En8 & RP_En2 & SI_En9 \\
\hline SI_En & & & & & & & & & & & & & \\
\hline SI_En2 & 56 & & & & & & & & & & & \\
\hline SD_En & 43 & 39 & & & & & & & & & & \\
\hline RI_En & 36 & 49 & 43 & & & & & & & & & \\
\hline SI_En3 & 35 & 37 & 64 & 49 & & & & & & & & & \\
\hline SI_En4 & 44 & 40 & 54 & 53 & 62 & & & & & & & & \\
\hline SI_En5 & 17 & 28 & 22 & 37 & 32 & 30 & & & & & & & \\
\hline SI_En6 & 28 & 30 & 37 & 56 & 43 & 61 & 44 & & & & & \\
\hline SI_En7 & 38 & 35 & 43 & 58 & 56 & 71 & 40 & 76 & & & & \\
\hline RP_En & 19 & 26 & 37 & 47 & 43 & 48 & 24 & 52 & 54 & & & & \\
\hline SI_En8 & 20 & 15 & 12 & 16 & 11 & 20 & 10 & 14 & 20 & 04 & & & \\
\hline RP_En2 & 32 & 30 & 28 & 35 & 30 & 37 & 33 & 41 & 42 & 31 & 14 & & \\
\hline SI_En9 & 30 & 28 & 26 & 30 & 32 & 40 & 26 & 29 & 35 & 24 & 21 & 38 & \\
\hline
\end{tabular}

*Individuals preceded by SI were collected in the Serra de Itabaiana National Park; individuals preceded by SD were collected in Simão Dias; individuals preceded by RI were collected in Ribeira; and individuals preceded by $\mathrm{RP}$ were collected in the village of Rio das Pedras, municipality of Itabaiana, State of Sergipe.

Clustering of Encyclia accessions revealed that the most divergent was specimen 8 collected in the Serra de Itabaiana National Park (SI_Encyclia8). The two most closely related specimens were collected in the park (SI_Encyclia and SI_Encyclia2) (78\%) (Figure 1). For Epidendrum L., the lowest degree of similarity (12\%) was found between E. secundum individuals collected in the municipality of Tomar do Geru and in the Serra de Itabaiana National Park (south and central regions of the state, respectively) (Table 4). SI_E. secundum, SI_E. secundum2, and SI_E. secundum 3 presented 100\% similarity by resampling (bootstrap). SI_E. secundum4, SI_E. secundum5, SI_E. secundum6, RdasP_E.secundum, and RdasP_E. secundum 2 formed the second cluster, with $83 \%$ similarity (Figure 2).

The Cattleya Lindley genus is only represented in the present collection by Cattleya tigrina A. Rich., although the occurrence of Cattleya labiata Lindl. has also been confirmed in the State of Sergipe (Monteiro et al., 2012a). Table 5 shows the similarity between the five specimens of the species Cattleya tigrina A. Rich of the studied collection. The genetic similarity ranged from 16 to $71 \%$ for Cattleya tigrina, with a mean similarity of $35.9 \%$. However, since the sample was limited, it is difficult to evaluate the real conservation status of the population, which is so far the only report on the species in the State of Sergipe.

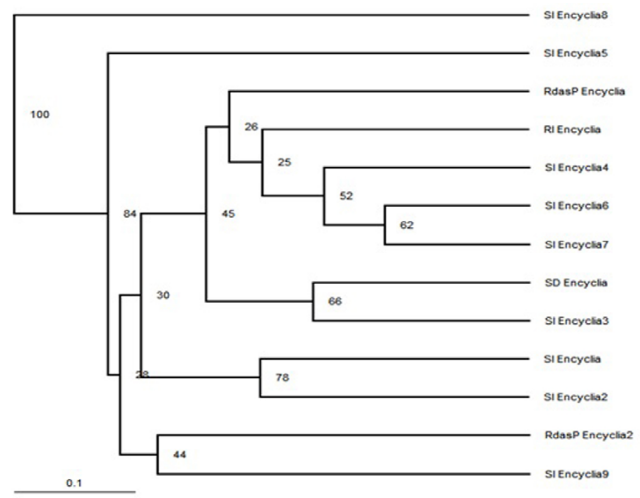

Figure 1. Unweighted pair group method with arithmetic mean (UPGMA) clustering of accessions of the genus Encyclia Hook from the Orchidaceae collection of the Federal University of Sergipe. 
Table 4. Jaccard similarity (\%) of individuals of the genus Epidendrum from the Orchidaceae collection of the Universidade Federal de Sergipe, collected in municipalities of the State of Sergipe (Brazil).

\begin{tabular}{l|c|c|c|c|c|c|c|c|c|c|c|c}
\hline & SI_E.s. & SI_E.s2 & SI_E.s3 & SI_E.s4 & SI_E.s5 & SI_E.s6 & RP_E.s & RP_E.s2 & TG_E.s & E.noc. & SI_E.059 & E.116 \\
\hline SI_E.s & & & & & & & & & & & & \\
\hline SI_E.s2 & 77 & & & & & & & & & & \\
\hline SI_E.s3 & 68 & 74 & & & & & & & & & \\
\hline SI_E.s4 & 28 & 36 & 34 & & & & & & & & & \\
\hline SI_E.s5 & 36 & 37 & 34 & 55 & & & & & & & & \\
\hline SI_E.s6 & 24 & 28 & 29 & 59 & 42 & & & & & & & \\
\hline RP_E.s & 36 & 41 & 43 & 64 & 46 & 59 & & & & & \\
\hline RP_E.s2 & 28 & 32 & 30 & 69 & 43 & 68 & 68 & & & & & \\
\hline TG_E.s & 12 & 21 & 22 & 26 & 25 & 29 & 28 & 33 & & & & \\
\hline E.noc. & 30 & 27 & 33 & 32 & 32 & 34 & 27 & 35 & 21 & & & \\
\hline SI_E.059 & 29 & 30 & 37 & 32 & 31 & 37 & 29 & 34 & 24 & 87 & & \\
\hline E.116 & 31 & 28 & 26 & 14 & 18 & 23 & 24 & 23 & 25 & 28 & 27 & \\
\hline
\end{tabular}

*Individuals preceded by SI were collected in Serra de Itabaiana National Park; individuals preceded by TG were collected in Tomar do Geru; and individuals preceded by RP were collected in the town of Rio das Pedras-Itabaiana, SE.

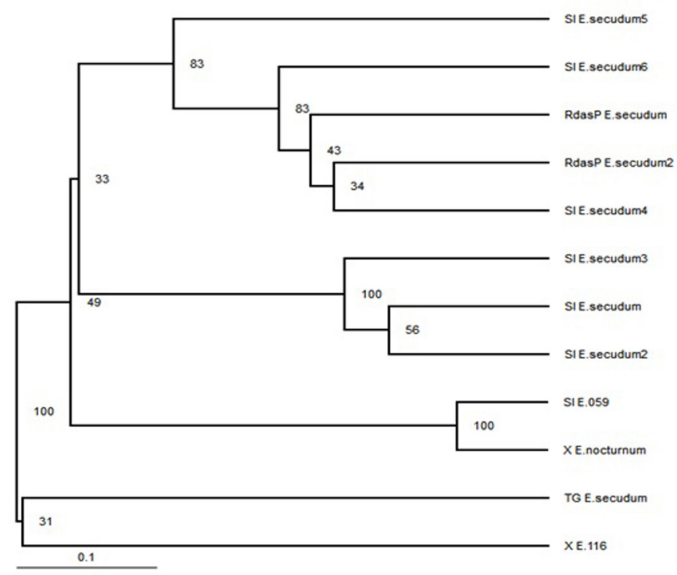

Figure 2. UPGMA clustering of accessions of the genus Epidendrum L. from the Orchidaceae collection of the Federal University of Sergipe.

By the resampling method (bootstrap), for instance, RD_Cat.tigrina3, RD_Cat. tigrina4, and RD_Cat.tigrina5 comprise a subcluster with $96 \%$ similarity among them and $72 \%$ similarity with RD_Cat.tigrina2 (Figure 3).

Table 5. Jaccard similarity (\%) of individuals of Cattleya tigrina from the Orchidaceae collection of the Universidade Federal de Sergipe, collected in municipalities of the State of Sergipe (Brazil).

\begin{tabular}{l|c|c|c|c|c}
\hline & RD_Cat.tigrina & RD_Cat.tigrina2 & RD_Cat.tigrina3 & RD_Cat.tigrina4 & RD_Cat.tigrina5 \\
\hline RD_Cat.tigrina & & & & & \\
\hline RD_Cat.tigrina2 & 23 & & & & \\
\hline RD_Cat.tigrina3 & 19 & 35 & & & \\
\hline RD_Cat.tigrina4 & 26 & 30 & 71 & & \\
\hline RD_Cat.tigrina5 & 16 & 27 & 60 & 52 & \\
\hline
\end{tabular}

*Individuals preceded by RD were collected in the municipality of Riachão de Dantas, State of Sergipe.

The joint analysis of Encyclia, Epidendrum, and Cattleya confirmed what was observed in the genus separately (Figure 4). Clustering was carried out primarily by genus/ species, regardless of the origin of the accessions. Epidendrum and Encyclia formed a cluster, 
which was divided into five subclusters. Ten of the 13 specimens of Encyclia comprised a subcluster. Another subcluster was formed by five E. secundum individuals, and the least similar was E. nocturnum and SI_E.059. RdasP_Encyclia2, SI_Encyclia9, SI_E.secundum, SI_E.secundum2, and SI_E.secundum3 made up the third subcluster. TG_E.secundum and E116 represent the fourth subcluster, and SI_Encyclia8, the fifth subcluster (Figure 4).

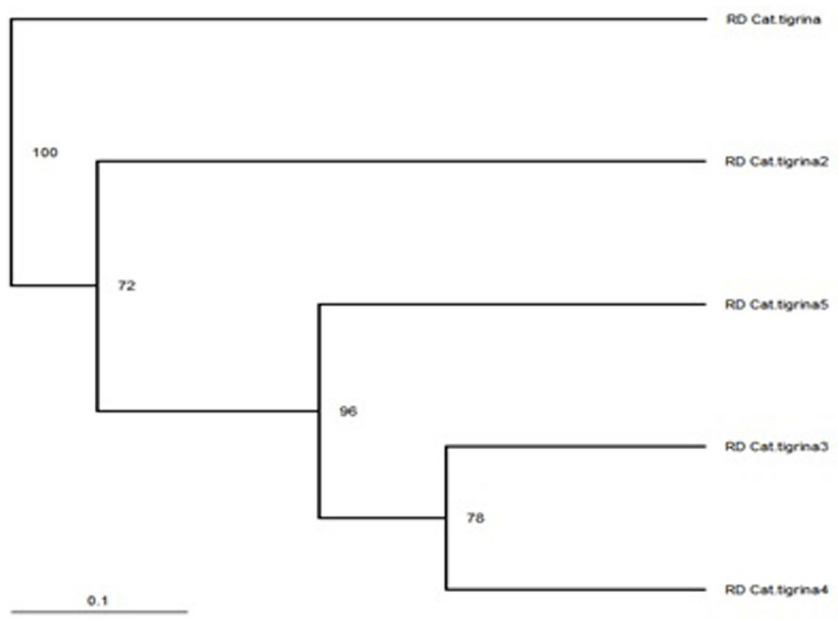

Figure 3. UPGMA clustering of accessions of Cattleya tigrina A. Rich. from the Orchidaceae collection of the Federal University of Sergipe.

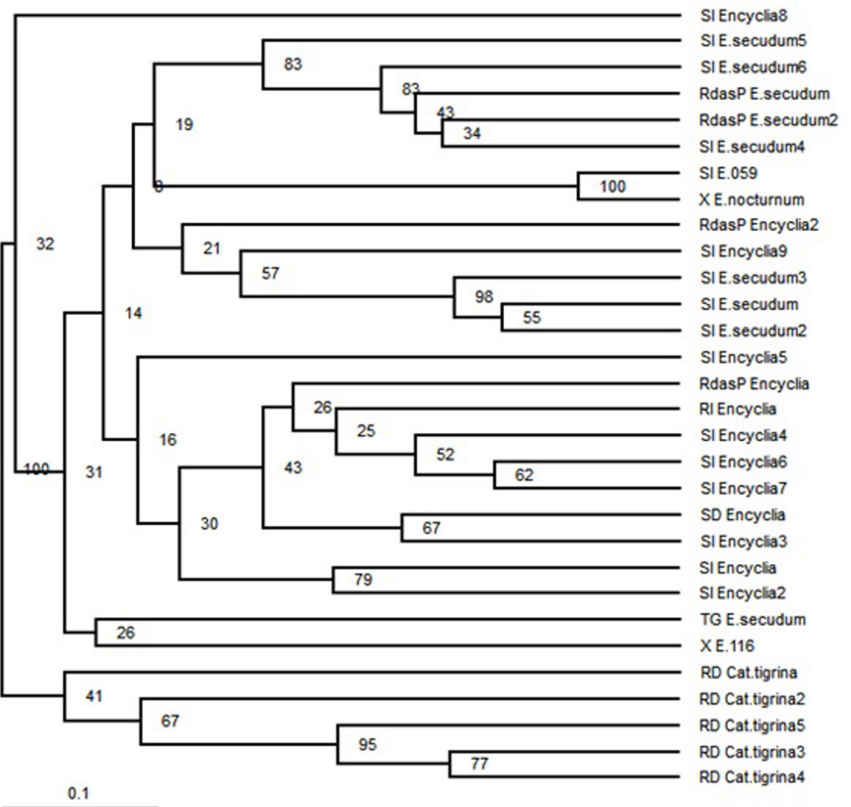

Figure 4. UPGMA clustering of the Laeliinae subtribe from the Orchidaceae collection of the Federal University of Sergipe. 


\section{DISCUSSION}

Several studies have been carried out using ISSR markers in orchid species. In Cymbidium goeringii, 25 ISSR primers produced a total of 210 polymorphic fragments, with a mean number of 8.4 fragments per primer (Wang et al., 2009). In Cattleya labiata, a mean number of 12.6 polymorphic fragments per ISSR primer was obtained (151 fragments produced by 12 primers), whereas 11 fragments per primer were obtained using RAPD markers in the same species. The results obtained in this study were close to those obtained with the same type of marker in Orchidaceae individuals (Pinheiro et al., 2012).

The highest and lowest similarity observed between individuals studied in the present article was independent of the location from which they were collected, suggesting that environmental variation does not significantly influence diversity (Figure 1).

Greater genetic similarity was observed between E. nocturnum individuals and an individual whose species has yet to be confirmed (SI_E059). The high similarity (87\%) suggests that SI_E059, which was collected in the Serra de Itabaiana National Park, is also a specimen of E. nocturnum. Another factor that supports this conclusion is the high level of similarity found between SI_E059 and E. secundum in this study (37\%) (Table 4).

The collected accessions of Epidendrum formed four clusters, and unlike Encyclia, specimens collected from close locations were found to be more genetically similar.

Confirming the results observed in the similarity table (Table 4), bootstrap analysis showed that SI_E059 (with 100\% similarity) clustered with E. nocturnum, which appears in the figure preceded by an "X", as it was donated to the collection with no origin identification. Confirmation of the identity of SI_E059 will only be possible after flowering, which will allow it to be classified based on morphological characteristics. TG_E.secundum, collected in the southern part of the Sergipe State (municipality of Tomar do Geru) and E.116 (Serra de Itabaiana National Park) were the most distinct, sharing 31\% similarity.

There is more to be learned about Brazilian genetic resources. Most studies performed in the northeast of Brazil, particularly those involving the Orchidaceae family, have involved inventories, floristic surveys, and taxonomic classification.

A study that surveyed and characterized the genus Catasetum in the State of Bahia provided a description of the taxa, identification keys, and illustrations of the six identified species (Bastos and Van Den Berg, 2012). A survey on Orchidaceae carried out in the State of Sergipe resulted in a list of 63 species, 34 of which were new records for the state (Monteiro et al., 2012a). Inventories carried out in Sergipe territory also served to include the state in the distribution map of some species, such as Encyclia alboxanthina Fowlie (Monteiro et al., 2012b).

The population of $C$. labiata found in the city of Poço Redondo - SE presented Jaccard similarities ranging from 29 to $74 \%$, with a mean value of 56\% (Pinheiro et al., 2012). Those authors also found mean similarities of $40-60 \%$ in other populations of the States of Pernambuco, Paraíba, and Ceará. Therefore, although they are isolated, populations conserve high intra-population variability, and this knowledge serves to define both the conservation strategy and the choice of individuals selected for improvement. The Laeliinae individuals studied in this article were found to have high genetic variation, especially between genera. Among the Encyclia specimen studied, SI_Encyclia8 was the least similar to the others. TG_E. secundum, collected in the southern state, presents less than $30 \%$ similarity with individuals of the same species collected in Serra de Itabaiana, and, therefore, is recommended for conservation purposes. Among Cattleya tigrina specimens, RD_Cat.tigrina differs from the others and should also be prioritized for conservation. 
Genetic diversity of Laeliinae

\section{Conflicts of interest}

The authors declare no conflict of interest.

\section{ACKNOWLEDGMENTS}

The authors thank CNPq (Conselho Nacional de Desenvolvimento Científico e Tecnológico), FAPEMIG (Fundação de Amparo à Pesquisa do Estado de Minas Gerais), and CAPES (Coordenação de Aperfeiçoamento de Pessoal de Nível Superior) for their financial support of this study.

\section{REFERENCES}

Altafin VL, Menezes MO, Lima RR and Pitombo LM (2003). Semeadura in vitro de orquídeas para propagação massal. Unipinhal, Espírito Santo do Pinhal.

Bastos CA and Van Den Berg C (2012). Flora da Bahia: Catasetum (Orchidaceae). Sitientibus- Ciênc. Biol. 12: 83-89.

Cai X, Feng Z, Hou B, Xing W, et al. (2012). Development of microsatellite markers for genetic diversity analysis of Dendrobium loddigesii Rolfe, an endangered orchid in China. Biochem. Syst. Ecol. 43: 42-47. http://dx.doi. org/10.1016/j.bse.2011.09.003

Chung MY and Chung MG (2010). Population genetic diversity and structure in Goodyera rosulaceae (Orchidaceae), endemic in Korea, and implications for conservation. Ann. Bot. Fenn. 47: 460-470. http://dx.doi.org/10.5735/085.047.0605

Doyle J (1991). DNA protocols for plants. In: Molecular techniques in taxonomy (Hewitt GM, Johnston, AWB and Young JPW eds.). Springer, Berlin, 283-293.

Fang H, Guo Q, Shen H and Li Y (2012). Genetic diversity evaluation of Chrysanthemum indicum L. by medicinal compounds and molecular biology tools. Biochem. Syst. Ecol. 41: 26-34. http://dx.doi.org/10.1016/j.bse.2011.12.013

George S, Sharma J and Yadon VL (2009). Genetic diversity of the endangered and narrow endemic Piperia yadonii (Orchidaceae) assessed with ISSR polymorphisms. Am. J. Bot. 96: 2022-2030. http://dx.doi.org/10.3732/ajb.0800368

Monteiro SHN, Carregosa T, Santos LAS, Nascimento JE, Junior., et al. (2012a). Survey of Orchidaceae from the State of Sergipe, Brazil. Biota Neotrop. 12: 167-174. http://dx.doi.org/10.1590/S1676-06032012000200016

Monteiro SHN, Santos LAS and Carregosa T (2012b). Expanding the distribution of Encyclia alboxanthina Fowlie (Orchidaceae, Laeliinae). Rev. Bras. Biocienc. 10: 248-250.

Moreira BMT, Tomba EC and Zonetti PC (2007). Crescimento in vitro de plântulas de orquídea (Laelia purpurata Lindl var venosa x Cattleya warneri T. Moore alba) sob diferentes concentrações de sacarose e frutose. Rev. Saúde Biol. 2: $16-21$.

Page RDM (1996). TreeView: an application to display phylogenetic trees on personal computers. Comput. Appl. Biosci. 12: 357-358.

Pavlicek A, Hrdá S and Flegr J (1999). Free Tree - freeware program for construction of phylogenetic trees on the basis of distance data and bootstrap/jackknife analysis of the tree robustness. Application in the RAPD analysis of genus Frenkelia. Folia Biol.-Prague 45: 97-99.

Pinheiro LR, Rabbani ARC, Silva AVC, Lédo AS, et al. (2012). Genetic diversity and population structure in the Brazilian Cattleya labiata (Orchidaceae) using RAPD and ISSR markers. Plant Syst. Evol. 12: 1815-1825. http://dx.doi. org/10.1007/s00606-012-0682-9

Raven PH, Evert RF and Eichhorn SE (2007). Biologia Vegetal. 7th edn. Guanabara Koogan, Rio de Janeiro.

Rech AR, Rosa YBCJ and Rosa-Junior EJ (2011). Levantamento e características ecológicas de Orchidaceae da mata ciliar do Rio Dourados, Dourados-MS. Rev. Arvore 35: 717-724. http://dx.doi.org/10.1590/S0100-67622011000400016

Sharma SK, Kumaria S, Tandon P and Rao SR (2011). Single primer amplification reaction (SPAR) reveals inter- and intra-specific natural genetic variation in five species of Cymbidium (Orchidaceae). Gene 483: 54-62. http://dx.doi. org/10.1016/j.gene.2011.05.013

Wang HZ, Wu ZX, Lu JJ, Shi NN, et al. (2009). Molecular diversity and relationships among Cymbidium goeringii cultivars based on inter-simple sequence repeat (ISSR) markers. Genetica 136: 391-399. http://dx.doi.org/10.1007/ s10709-008-9340-0

Watanabe D (2002). Orquídeas: manual de cultivo. 2nd edn. Associação Orquidófila de São Paulo, São Paulo.

Genetics and Molecular Research 15 (2): gmr.15027997

CFUNPEC-RP www.funpecrp.com.br 